\title{
Implementation of PPI with Nano Amorphous Oxide Semiconductor Devices for Medical Applications [Corrigendum]
}
Dai $\mathrm{M}, \mathrm{Wu} \mathrm{Z}$, Qi $\mathrm{S}$, et al. Int $J$ Nanomedicine.
The authors apologize for this error and advise it does not 2020;15:1863-1870.

The authors have advised that due to a mismatch between the device and the SEM, Figure 1C and D on page 1865 are incorrect. The correct Figure 1 is shown below.
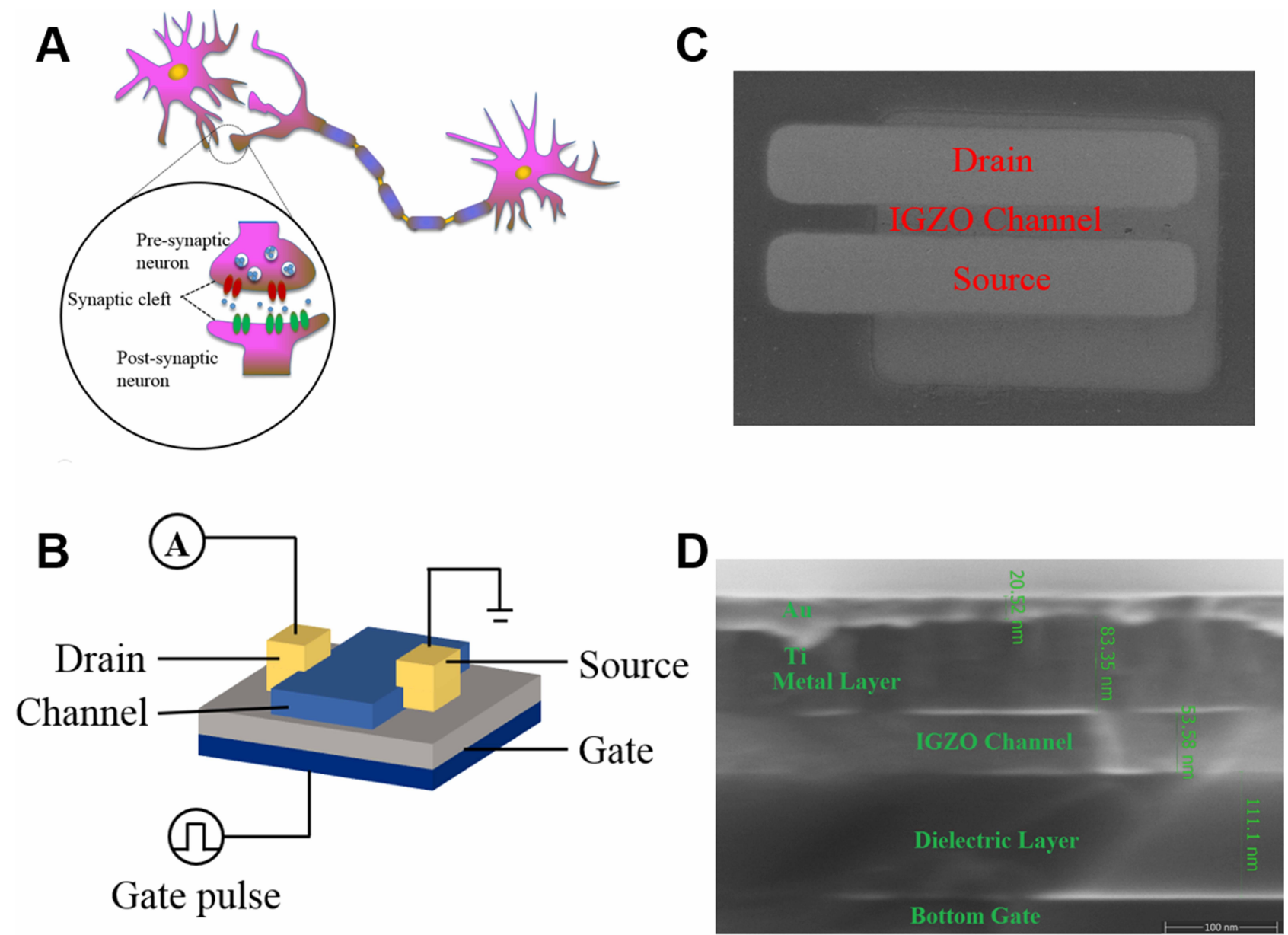

Figure I Schematic of the IGZO-based artificial bio synapses, i.e., IGZO TFT. (A) The typical structure of synapses, including the synaptic cleft: pre- and postsynaptic neuron parts. (B) An IGZO TFT device bottom gate structure and the proposed measurement of representative synaptic transmission behavior in IGZO TFT. (Voltage is applied to the bottom gate, and the drain current is the bionic neural signal). (C) SEM top image of IGZO TFTs with an IGZO channel between the source and the drain top electrodes (scale bar=300 $\mu \mathrm{m}$ ). (D) SEM image of IGZO TFTs layers cross section (scale bar $=100 \mathrm{~nm}$ ). 


\section{Publish your work in this journal}

The International Journal of Nanomedicine is an international, peerreviewed journal focusing on the application of nanotechnology in diagnostics, therapeutics, and drug delivery systems throughout the biomedical field. This journal is indexed on PubMed Central, MedLine, CAS, SciSearch ${ }^{\mathbb{R}}$, Current Contents ${ }^{\mathbb{R}} /$ Clinical Medicine,
Journal Citation Reports/Science Edition, EMBase, Scopus and the Elsevier Bibliographic databases. The manuscript management system is completely online and includes a very quick and fair peer-review system, which is all easy to use. Visit http://www.dovepress.com/ testimonials.php to read real quotes from published authors.

Submit your manuscript here: https://www.dovepress.com/international-journal-of-nanomedicine-journal 